\title{
SOLUBILITY OF PRECURSORS AND CARBONATION OF WATERGLASS-FREE GEOPOLYMERS
}

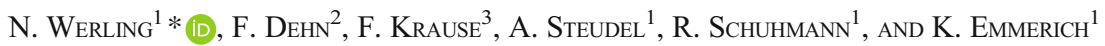 \\ ${ }^{1}$ Competence Center for Material Moisture (CMM), Karlsruhe Institute of Technology (KIT), Hermann-von-Helmholtz-Platz 1, \\ 76344 Eggenstein-Leopoldshafen, Germany \\ ${ }^{2}$ Institute for Concrete Structures and Building Materials (IMB), Karlsruhe Institute of Technology (KIT), Gotthard-Franz-Str. 3, \\ 76131 Karlssuhe, Germany \\ ${ }^{3}$ Institute of Functional Interfaces (IFG), Karlsruhe Institute of Technology (KIT), Hermann-von-Helmholtz-Platz 1, 76344 Eggenstein- \\ Leopoldshafen, Germany
}

\begin{abstract}
Geopolymers have the potential to function as an environmentally friendly substitute for ordinary Portland cement, with up to $80 \%$ less $\mathrm{CO}_{2}$ emission during production. The effect is best utilized for geopolymers prepared with amorphous silica instead of waterglass $\left(\mathrm{Na}_{2 x} \mathrm{Si}_{y} \mathrm{O}_{2 y+x}\right)$ to adjust the $\mathrm{Si}$ :Al ratio. The reactivity of the precursors with the alkaline activator affects the final mineralogical properties of the binder. The purpose of the present study was to investigate the amount of different phases formed during geopolymerization and to understand the quantitative evolution of carbonation during geopolymer synthesis by determining the solubility of metakaolinite and amorphous $\mathrm{SiO}_{2}$ in $\mathrm{NaOH}$ at various concentrations. The solubility was studied by ICP-OES measurements. X-ray diffraction was used for qualitative and quantitative phase analysis of the geopolymers. The solubility of the precursors increased with calcination temperature of metakaolinite, reaction time for amorphous $\mathrm{SiO}_{2}$, and at higher $\mathrm{NaOH}$ concentrations. Partial dissolution resulted in free $\mathrm{Na}^{+}$, which is a source for the formation of carbonates in the geopolymers. Thermonatrite occurred prior to trona formation in all samples.
\end{abstract}

Keywords-Amorphous silica $\cdot$ Carbonation $\cdot$ Geopolymers $\cdot$ Metakaolinite

\section{INTRODUCTION}

Geopolymer binders are inorganic polymers with a 3-dimensional framework structure of oligomers with various ratios of $\mathrm{Si}, \mathrm{Al}, \mathrm{O}$, and $\mathrm{OH}^{-}$. The negative charge created by $\mathrm{Si} / \mathrm{Al}$ substitutions is balanced by the cation of the alkaline activator solution. As well as supplementary cementitious materials (SCM), geopolymer binders are potential substitutes for ordinary Portland cement (OPC), and emit up to $40-80 \%$ less $\mathrm{CO}_{2}$ than OPC during their production (McLellan et al. 2011; Davidovits 2013). The lower emissions are mainly due to the fact that the raw materials contain no structural $\mathrm{CO}_{2}$. In contrast to $\mathrm{SCM}$, which replace only a certain amount of OPC, geopolymers are ideally OPC-free binders. OPC is a hydraulic binder, while geopolymers are alkaline-activated binders. High-Ca and low-Ca/Ca-free types of alkaline-activated binders differ from one another (Herrmann et al. 2018) in that geopolymers contain little or no Ca. Aluminosilicates (fly ash, furnace slag, silica fume, or calcined clays) function as precursors and are activated with a highly alkaline solution (waterglass and/or highly concentrated alkali brines), which leads to a geopolymerization reaction (Davidovits 1991). The polymerization takes place in three successive reactions: the dissolution of the precursors in the alkaline activator solution; the reorganization and diffusion of monomers; and, afterwards, the formation of the 3-dimensional network and hardening of the binder (Heah et al. 2013; Esaifan et al. 2015).

* E-mail address of corresponding author: nadja.werling@kit.edu DOI: $10.1007 / \mathrm{s} 42860-020-00096-4$

(C) The Author(s) 2020
The mechanical properties of geopolymers are comparable to those of binders prepared with OPC (Oh et al. 2010; Gao et al. 2014; Djobo et al. 2016; Yaseri et al. 2017; Hàjkovà 2018). When calcined clay minerals such as metakaolinite $(\mathrm{Si}: \mathrm{Al}=1: 1)$ are used as a precursor, adjusting the Si:Al ratio may be necessary to optimize the mechanical performance of the geopolymers (Duxson et al. 2005; Ozer and Soyer-Uzun 2015; Yaseri et al. 2017). A Si:Al ratio of 3:1 is given as a suitable ratio (Davidovits 1982; Yaseri et al. 2017). For this purpose, commercial waterglass solutions are mostly used for the production of geopolymers. The term waterglass describes aqueous solutions of the glassy frozen melts of alkali silicates, mostly sodium silicates, with varying $\mathrm{SiO}_{2}: M_{2} \mathrm{O}(M: \mathrm{Na}, \mathrm{K}$, or $\mathrm{Li})$ ratios (e.g. $\left.\mathrm{Na}_{2} \mathrm{SiO}_{3}\right)$. In the production of geopolymers, however, waterglass accounts for most of the $\mathrm{CO}_{2}$ emissions. The environmental benefit is reduced by commercial waterglass, therefore, in comparison with OPC cements. The usage of alkaline brines (e.g. $\mathrm{NaOH}$ ) can lead to a reduction in $\mathrm{CO}_{2}$ emissions of up to $50 \%$ and the $\mathrm{Si}: \mathrm{Al}$ ratio can be adjusted by alternative $\mathrm{SiO}_{2}$ sources (Mellado et al. 2014). Microcrystalline or amorphous $\mathrm{SiO}_{2}$ can be obtained by combustion of organic materials or by technical manufacturing (e.g. silica fume). Rice husk ash appeared to be suitable for producing an alkalineactivator solution in combination with $\mathrm{NaOH}$ (He et al. 2013; Tchakouté et al. 2016). Furthermore, waste glass and sugar cane bagasse ash performed well in terms of geopolymer production (Tchakouté et al. 2016, 2017). The solubility of any other alternative $\mathrm{SiO}_{2}$ sources in $\mathrm{NaOH}$ was not considered here. The

Electronic supplementary material The online version of this article (https://doi.org/10.1007/s42860-020-00096-4) contains supplementary material, which is available to authorized users. 
solubility of $\mathrm{SiO}_{2}$ in alkaline solutions was investigated only up to a pH value of 12 (Alexander et al. 1954; Crundwell 2017).

In addition, unreacted metakaolinite remains following the production of geopolymers (Rowles and O'Connor 2003; Duxson et al. 2005; Heah et al. 2013; Esaifan et al. 2015; Faisal et al. 2015), but usually the amount of unreacted material and the range of the solubility of metakaolinite in the alkaline activator have not been investigated further. The solubility of clay minerals increases with the concentration of $\mathrm{NaOH}$ (Xu and Van Deventer 2003). In addition, geopolymers produced with more concentrated $\mathrm{NaOH}$ show greater compressive strengths (Heah et al. 2013). Research on clay-mineral solubility in alkaline environments is carried out mainly in the field of nuclear-waste storage. The highest concentration of alkaline solution used is $4 \mathrm{~mol} / \mathrm{L}$ (Chermak 1992; Bauer and Berger 1998; Cuevas et al. 2006).

The solubility of metakaolinite and $\mathrm{SiO}_{2}$ at $\mathrm{pH}=14$ and at high $\mathrm{NaOH}$ concentrations should be investigated with respect to the amount of unreacted material left after geopolymerization. Unreacted material must be considered because of its impact on the compressive strength and carbonation (formation of carbonates) of geopolymers. While unreacted material can act as a filler and increase mechanical strength (Xu and Van Deventer 2000; Moosberg-Bustnes et al. 2004), a non-stoichiometric conversion of precursors and activator will lead to unreacted $\mathrm{Na}^{+}$and carbonation. Carbonation was observed in various geopolymers (e.g. Fletcher et al. 2005; Zaharaki et al. 2010; Nikolov et al. 2017), but a quantitative description was not given.

The present study investigated geopolymers prepared using metakaolinite and $\mathrm{NaOH}$ but without commercial waterglass. The Si:Al ratio was adjusted by amorphous $\mathrm{SiO}_{2}$. The objective was first to determine quantitatively the solubility of metakaolinite and amorphous $\mathrm{SiO}_{2}$ and second to study the carbonation of geopolymers prepared with the initial Si:Al:Na ratio ranging from $1: 1: 1$ to $3: 1: 1$ with the expected incomplete dissolution of the precursors.

\section{MATERIALS AND METHODS}

\section{Raw Materials}

The Bavarian kaolin KBE-1 (grain size $\leq 20 \mu \mathrm{m}$ ) from Amberger Kaolinwerke Eduard Kick GmbH \& Co. KG (Hirschau, Bavaria, Germany) was used to produce metakaolin by calcination. The calcination of KBE-1 was carried out at $480,555,615,700$, and $900^{\circ} \mathrm{C}$ in a $\mathrm{L} 9 / 12 / \mathrm{B} 180$ furnace from Nabertherm (Lilienthal, Germany). These temperature steps were selected based on the dehydroxylation of kaolinite (beginning at the onset of DHX and ending prior to recrystallization) determined by thermal analysis (see supplementary material, Fig. S1). Samples were heated at a rate of $10 \mathrm{~K} / \mathrm{min}$ in air without forced recirculation. No holding time at maximum temperature was applied. The raw material contained 93\% kaolinite and small amounts of accessory minerals (Table 1). The metakaolin consisted mainly of metakaolinite, therefore. This term will be used through the manuscript to describe the samples.
Table 1. Proportions (wt.\%) of mineral phases present in KBE-1

\begin{tabular}{lllll}
\hline Phase & Kaolinite & Muscovite/lllite & Quartz & Anatase \\
\hline $93 \pm 0.5$ & $5.5 \pm 0.5$ & $1.0 \pm 0.5$ & $<0.5$ \\
\hline
\end{tabular}

Kaolinite of KBE1 consists of 46-47 mass\% ordered kaolinite and 50-51 mass \% disordered kaolinite. The disordered kaolinite is characterized by $93 \% \mathrm{~B} / 7 \% \mathrm{BC}$ stacking sequences. $88 \%$ of BB sequences have no additional $b / 3$ stacking errors and, thus, the kaolinite is low $b$-axis error-ordered. The Hinckley index of KBE1_M2 was 1.63, characteristic of a well ordered kaolinite (Izadifar et al. 2020).

Amorphous silica (Amosil® from HPF - The Mineral Engineers, Frechen, Germany; grain size $\leq 12 \mu \mathrm{m}$; Table 2) was added to adjust the $\mathrm{Si}$ :Al ratio of the geopolymers.

Ultra-pure $\mathrm{NaOH}$ solutions (Carl Roth $\mathrm{GmbH} \&$ Co.KG, Karlsruhe, Germany) with concentrations of $10.79 \mathrm{~mol} / \mathrm{L}$ (32\%), $7.96 \mathrm{~mol} / \mathrm{L}(25 \%), 6.1 \mathrm{~mol} / \mathrm{L}(20 \%), 5 \mathrm{~mol} / \mathrm{L}$ $(16.88 \%)$, and $4 \mathrm{~mol} / \mathrm{L}(13.9 \%)$ were utilized. Solutions with concentrations of $1 \mathrm{~mol} / \mathrm{L}(3.8 \%), 0.1 \mathrm{~mol} / \mathrm{L}(0.38 \%)$, and $0.01 \mathrm{~mol} / \mathrm{L}(0.038 \%)$ were also prepared.

\section{Analytical Techniques}

Inductively coupled plasma optical emission spectrometry (ICP-OES) was carried out using an Optima 8300DV instrument (Perkin Elmer, Waltham, Massachusetts, USA). The measuring range of $\mathrm{Si}$ and $\mathrm{Al}$ concentrations in solution was $30 \mathrm{mg} / \mathrm{L}$. Liquid samples were, therefore, diluted by a factor of 200.

For X-ray diffraction (XRD), a Bruker D8 Advance A25 diffractometer (Bruker AXS GmbH, Karlsruhe, Germany) with a LYNXEYE XE Detector (2.94 opening angle) was used. Powdered samples $(<32 \mu \mathrm{m})$ and solid geopolymer discs were analyzed between 5 and $80^{\circ} 2 \theta$ or between 2 and $60^{\circ} 2 \theta$. The step size was $0.02^{\circ} 2 \theta$ and the scan rate was $2 \mathrm{~s}$ per step. An automatic slit (primary side), Soller collimators of $2.5^{\circ}$ (primary and secondary sides), and an automatic knife edge were used. The $\mathrm{CuK} \alpha$ radiation $(1.54 \AA)$ was generated at $40 \mathrm{kV}$ and $35 \mathrm{~mA}$. For quantitative analysis, the Rietveld software Autoquan (GE Inspection Technologies $\mathrm{GmbH}$, Boston, Massachusetts USA) was used.

Investigations with a scanning electron microscope (SEM) were conducted using a VEGA3 instrument (TESCAN, Brno, Czech Republic). First, solid discs of geopolymer were used without polishing to study the sample surface. For further investigations, cross sections of the discs were embedded in epoxy resin (Epoxy2000 from Cloeren Technology GmbH, Wegberg, Germany) and polished. The tests were complemented by EDX analysis (measuring field of $250 \mu \mathrm{m} \times 250 \mu \mathrm{m}$ ).

Table 2. Composition of amorphous silica - Amosil® (wt.\%)

\begin{tabular}{cccccc}
\hline Constituents & $\mathrm{SiO}_{2}$ & $\mathrm{Al}_{2} \mathrm{O}_{3}$ & $\mathrm{Fe}_{2} \mathrm{O}_{3}$ & $\mathrm{CaO}+\mathrm{MgO}$ & $\mathrm{Na}_{2} \mathrm{O}+\mathrm{K}_{2} \mathrm{O}$ \\
\hline 99 & 0.3 & 0.03 & 0.03 & 0.03 \\
\hline
\end{tabular}


Table 3. Composition of blends

\begin{tabular}{|c|c|c|c|c|c|c|c|}
\hline Geopolymer sample & Si:Al ratio & $\mathrm{NaOH}$ concentration $(\mathrm{mol} / \mathrm{L})$ & $\mathrm{s} / 1$ & $1 / \mathrm{s}$ & Metakaolinite (g) & Amorphous silica (g) & $\mathrm{NaOH}(\mathrm{g})$ \\
\hline GP1 & $1: 1$ & 10.79 & 0.89 & 1.13 & 5 & - & 5.63 \\
\hline GP2 & $2: 1$ & 6.1 & 0.86 & 1.17 & 3.25 & 1.76 & 5.85 \\
\hline GP3 & $2: 1$ & 7.96 & 1.07 & 0.94 & 3.25 & 1.76 & 4.68 \\
\hline GP4 & $3: 1$ & 4 & 0.8 & 1.24 & 2.45 & 2.65 & 6.34 \\
\hline GP5 & $3: 1$ & 5 & 0.98 & 1.03 & 2.45 & 2.65 & 5.23 \\
\hline GP6 & $3: 1$ & 6.1 & 1.16 & 0.86 & 2.45 & 2.65 & 4.41 \\
\hline GP7 & $3: 1$ & 7.96 & 1.44 & 0.69 & 2.45 & 2.65 & 3.53 \\
\hline
\end{tabular}

\section{EXPERIMENTAL PROCEDURE}

\section{Determination of Dissolution Characteristics}

$0.1 \mathrm{~g}$ of either raw KBE-1, metakaolinite, or amorphous $\mathrm{SiO}_{2}$ was mixed with $5 \mathrm{~g}$ of $\mathrm{NaOH}$ solution, which is equal to a solid/liquid ( $\mathrm{s} / \mathrm{l}$ ) ratio of 0.02 . The $\mathrm{NaOH}$ solutions reflected a $\mathrm{pH}$ value ranging between 12 and 14. The samples were left on a shaking table for $24 \mathrm{~h}$ or 7 days. Afterward the samples were centrifuged for $25 \mathrm{~min}$ at $4347 \times \mathrm{g}$. $0.5 \mathrm{~mL}$ of supernatant was diluted in each case for ICP-OES measurement.

\section{Geopolymer Production}

The geopolymers were manufactured with the metakaolinite calcined at $700^{\circ} \mathrm{C}$, to ensure fully dehydroxylated material (see supplementary material, Fig. S1). After calcination, the metakaolinite was ground manually and gently to destroy small aggregates which were formed during calcination. Metakaolinite has a natural $\mathrm{Si} A \mathrm{Al}$ ratio of $1: 1$. The $\mathrm{Si}: \mathrm{Al}$ ratio was increased to the supposed optimum of $3: 1$ by adding amorphous silica as a solid powder in various amounts (Table 3 ). The $\mathrm{Na}$ :Al ratio was fixed at 1:1 and, thus, the s/l ratio varied (Table 3). In preliminary tests, $\mathrm{s} / 1$ ratios of between 0.8 and 2 yielded sufficient hardening and good workability. S/1 ratios of $<0.8$ led to mixtures with very low viscosity and insufficient hardening. If the $\mathrm{NaOH}$ concentration was too high, its volume in the formulation was too low (s/1 > 2) and workability was lost.

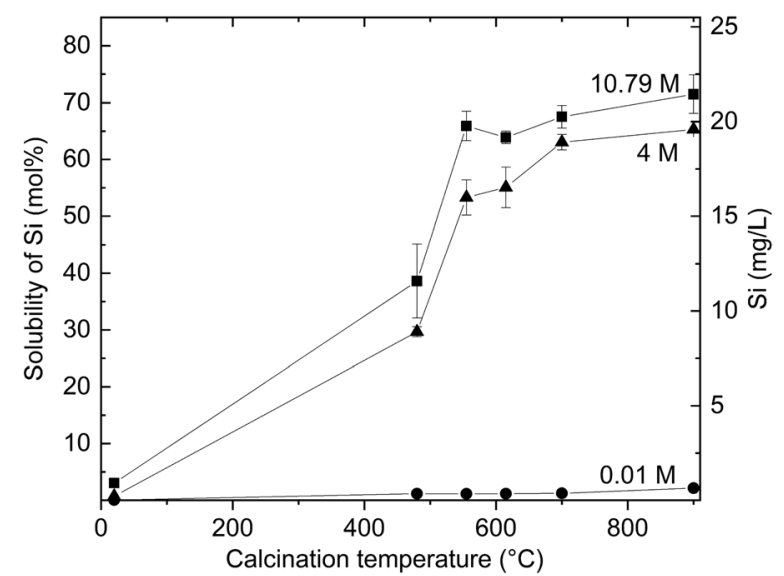

Fig. 1 Solubility of KBE-1 in $\mathrm{NaOH}(10.79 \mathrm{~mol} / \mathrm{L}, 4 \mathrm{~mol} / \mathrm{L}, 1 \mathrm{~mol} / \mathrm{L})$ as a function of calcination temperature (reaction time $24 \mathrm{~h}$ )
The solids were mixed with the $\mathrm{NaOH}$ solutions for several minutes at 10,000 rpm using a Roti-Speed-Stirrer (Xenox MHX/E from Proxxon, Wecker, Luxembourg) operated at $40 \mathrm{~W}$. Next, the stirred material was placed on a vibration table (Vortex Genie 2 from Scientific Industries Inc., Bohemia, New York, USA) for several more minutes to avoid trapped air in the hardening samples. The hardening took place in open PE cylinders (from Kulzer $\mathrm{GmbH}$, Hanau, Germany) with $30 \mathrm{~mm}$ diameter under ambient conditions $\left(\sim 21^{\circ} \mathrm{C}, \sim 50 \%\right.$ relative humidity). Three days after preparation, the geopolymer discs were subjected to XRD for qualitative phase analysis. For quantitative analysis, powdered samples were prepared from a second set of geopolymer discs prepared in parallel. They were crushed after 1 day of hardening and ground gently after the second day. After 3 days, the samples were ground again and sieved $(<32 \mu \mathrm{m})$. As an internal standard, $10 \mathrm{wt} \% \mathrm{ZnO}$ was added. XRD analysis of the powdered samples also started at a sample age of 3 days.

\section{RESULTS AND DISCUSSION}

Solubility of Metakaolinite and Amorphous Silica

Kaolinite and metakaolinite showed a congruent solubility of $\mathrm{Si}$ and $\mathrm{Al}$ (for solubility of Al see supplementary material, Fig. S2). Non-congruent solubility would lead to an excess or a

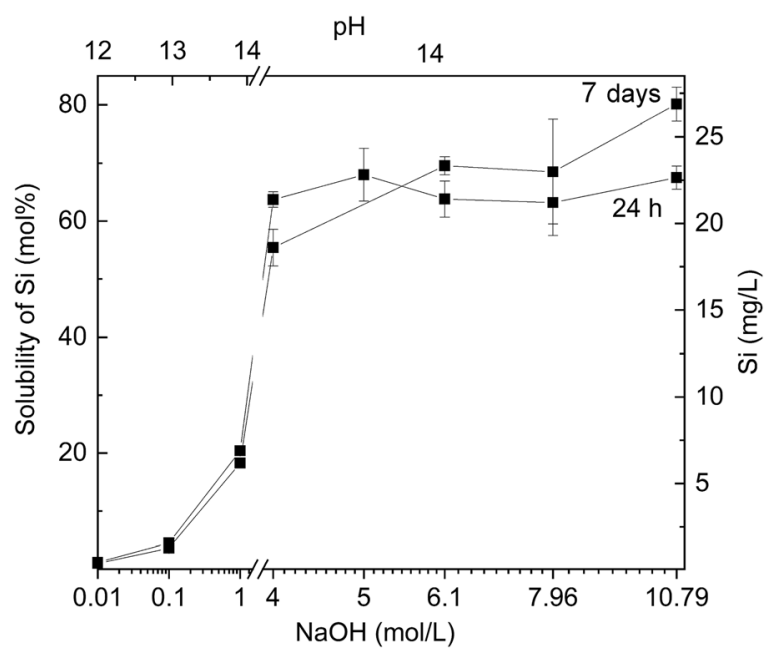

Fig. 2 Solubility of metakaolinite (KBE-1 calcined at $\left.700^{\circ} \mathrm{C}\right)$ at various $\mathrm{NaOH}$ concentrations (reaction time $24 \mathrm{~h}$ and 7 days) 
Table 4. Estimated amounts of free $\mathrm{Na}^{+}$and thermonatrite

\begin{tabular}{lll}
\hline Geopolymer sample & Surplus $\mathrm{Na}^{+}(\mathrm{mol})$ & Thermonatrite (wt.\%) \\
\hline GP1 & 0.015 & 11.2 \\
GP2 & 0.010 & 8.2 \\
GP3 & 0.011 & 8.5 \\
GP4 & 0.008 & 7 \\
GP5 & 0.007 & 6.4 \\
GP6 & 0.008 & 7.5 \\
GP7 & 0.008 & 7.9 \\
\hline
\end{tabular}

deficit of $\mathrm{Al}$ in the geopolymer matrix. The samples that were not calcined presented the lowest solubility $(<5 \%$, Fig. 1$)$. The solubility increased by $>20 \%$ after the calcination temperature was increased from 480 to $555^{\circ} \mathrm{C}$. At calcination temperatures of $>555^{\circ} \mathrm{C}$ the increase in solubility declined $(\leq 10 \%)$. The maximum solubility (e.g. $65 \%$ in $4 \mathrm{~mol} / \mathrm{L}$ and $71.5 \%$ in $10.79 \mathrm{~mol} / \mathrm{L} \mathrm{NaOH}$ ) was reached in sample KBE-1 calcined at $900^{\circ} \mathrm{C}$ (Fig. 1). This trend was observed in all $\mathrm{NaOH}$ concentrations. The solubility of samples calcined at 700 and $900^{\circ} \mathrm{C}$ differed only slightly $(0-5 \%)$. Calcination to $700^{\circ} \mathrm{C}$ is sufficient, therefore, for geopolymer production.

The solubility of metakaolinite calcined at $700^{\circ} \mathrm{C}$ increased with the concentration of $\mathrm{NaOH}$ (Fig. 2). In 0.01 and $0.1 \mathrm{~mol} / \mathrm{L}$, solubilities of $<5 \%$ were reached even after 7 days. The greatest solubility for the same metakaolinite was reached in $10.79 \mathrm{~mol} / \mathrm{L} \mathrm{NaOH}$ after 7 days (80\%, Fig. 2). Note that none of the samples reached a solubility of $100 \%$. At the beginning of geopolymer formation, the incomplete dissolution of metakaolinite in $\mathrm{NaOH}$ led to an excess of unreacted $\mathrm{Na}^{+}$in the mixture. This unreacted $\mathrm{Na}^{+}$formed carbonates (thermonatrite at first) from reaction with airborne $\mathrm{CO}_{2}$. Theoretical amounts of free $\mathrm{Na}^{+}$and thermonatrite (Table 4) were estimated based on the solubility of metakaolinite after $24 \mathrm{~h}$ (Fig. 2) and the assumption that the solubility of metakaolinite

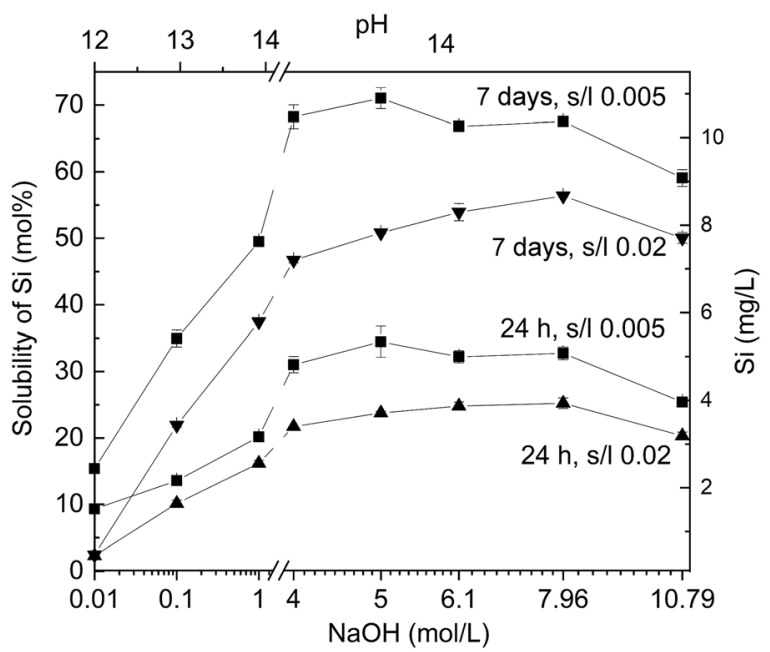

Fig. 3 Solubility of amorphous silica at various $\mathrm{NaOH}$ concentrations (reaction times of $24 \mathrm{~h}$ and 7 days)

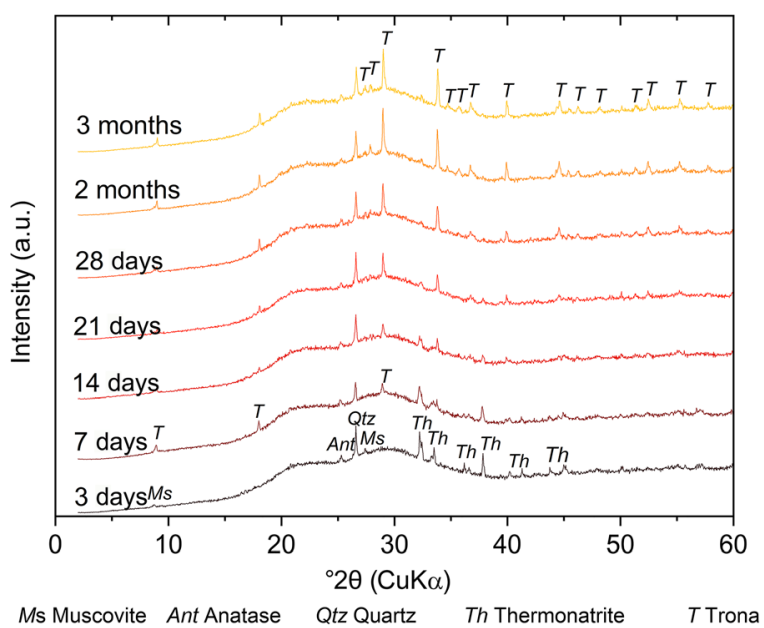

Fig. 4 Qualitative phase analysis of GP7 over a period of 3 months

is not influenced by the dissolution of amorphous $\mathrm{SiO}_{2}$ in geopolymer formulation. Excess $\mathrm{Na}^{+}$is determined by the amount of metakaolinite (s/l) and its solubility in the specific $\mathrm{NaOH}$ in the geopolymer formulation. As solubility of metakaolinite in $\mathrm{NaOH}$ with a concentration of $\geq 4 \mathrm{~mol} / \mathrm{L}$ varies only slightly, the samples with higher s/l (with the same amount of metakaolinite) must contain a larger amount of thermonatrite. GP2 has a calculated amount of thermonatrite of $8.17 \mathrm{wt} . \%$ (s/1 0.86 ) while that of GP3 is slightly larger with $8.50 \mathrm{wt} . \%$ (s/1 1.07). The same goes for GP4-7 (s/1 0.80-1.44). The slightly smaller amount of thermonatrite calculated for GP5 compared to GP4 is a result of the greater solubility of metakaolinite measured at $5 \mathrm{~mol} / \mathrm{L} \mathrm{NaOH}$. The largest amount of thermonatrite at the beginning of the geopolymerization was found in GP1.

The solubility of amorphous silica was between 20 and $25 \%$ after $24 \mathrm{~h}$ and up to $55 \%$ after 7 days at a s/1 ratio of 0.02 (Fig. 3). The solubility in $10.79 \mathrm{~mol} / \mathrm{L} \mathrm{NaOH}$ was slightly less than in $7.96 \mathrm{~mol} / \mathrm{L} \mathrm{NaOH}$. By lowering the s/1 to 0.005 , the

Table 5. Si:Al ratios for GP, calculated by solubilities of metakaolinite and amorphous $\mathrm{SiO}_{2}$

\begin{tabular}{lllll}
\hline Geopolymer & $\begin{array}{l}\text { Dissolved } \mathrm{Si} \approx \mathrm{Al} \\
(\text { metakaolinite })^{1} \\
(\mathrm{~mol})\end{array}$ & $\begin{array}{l}\text { Dissolved Si } \\
(\text { amorphous } \\
\left.\mathrm{SiO}_{2}\right)^{1,2} \\
(\mathrm{~mol})\end{array}$ & $\begin{array}{l}\text { Total } \\
\mathrm{Si} \text { in } \\
\mathrm{GP}^{3} \\
(\mathrm{~mol})\end{array}$ & $\begin{array}{l}\mathrm{Si} \text { in GP } \\
(\mathrm{after}\end{array}$ \\
\hline 24 h)
\end{tabular}

1 normalized solubility of metakaolinite

${ }^{2} 0.25 y \mathrm{Si}(y=1$ or 2$)$

${ }^{3} x \mathrm{Si}+0.25 y \mathrm{Si}(x$ : normalized solubility of metakaolinite) 
Table 6. First appearance of carbonates in geopolymer discs (determined by XRD)

\begin{tabular}{llllllll}
\hline & GP1 & GP2 & GP3 & GP4 & GP5 & GP6 & GP7 \\
\hline \multicolumn{7}{c}{$\begin{array}{c}\text { Occurrence } \\
\text { (days) }\end{array}$} \\
Thermonatrite & 3 & 7 & 3 & 7 & 7 & 7 & 3 \\
Trona & 14 & 14 & 7 & 14 & 7 & 14 & 7 \\
\hline
\end{tabular}

solubility had already increased after $24 \mathrm{~h}$. At 7 days, a maximum of $70 \%$ was reached in $5 \mathrm{~mol} / \mathrm{L} \mathrm{NaOH}$ (Fig. 3). Because the solubility of amorphous silica at a $\mathrm{s} / 1$ ratio of 0.02 was only $20-25 \%$ in $\mathrm{NaOH}$ of 4-7.96 mol/L after $24 \mathrm{~h}$, even less $\mathrm{SiO}_{2}$ dissolution after $24 \mathrm{~h}$ could be assumed during geopolymer production with a much higher s/1 ratio of $0.8-1.44$. To estimate the resulting $\mathrm{Si}: \mathrm{Al}$ of the geopolymer matrix after $24 \mathrm{~h}$, however, a solubility of $25 \%$ was considered (Table 5).

\section{Phase Composition of Geopolymers}

All the geopolymers described in this study hardened, and those prepared with $\mathrm{NaOH}$ concentrations of $>5 \mathrm{~mol} / \mathrm{L}$ showed compressive strengths of a few MPa. Further study and the optimization of mechanical properties were not the aim of the present study, however.

The formation of carbonates during the early stages of hardening was evident from the appearance of white efflorescence at the surface of the geopolymer discs and confirmed by XRD (Fig. 4). First, thermonatrite $\left(\mathrm{Na}_{2} \mathrm{CO}_{3} \cdot \mathrm{H}_{2} \mathrm{O}\right)$ and, shortly afterward, trona $\left(\mathrm{Na}_{3}\left(\mathrm{HCO}_{3}\right)\left(\mathrm{CO}_{3}\right) \cdot 2 \mathrm{H}_{2} \mathrm{O}\right)$ were formed. For GP1, GP3, and GP7 the carbonation started after 3 days; for the other GP samples, carbonates first appeared at a sample age of 7 days (Table 6). While the amount of trona increased for up to 3 months, thermonatrite disappeared with time; after 28 days, thermonatrite could no longer be detected (Fig. 4).

In the powdered samples, small amounts of trona (1.133.59 wt.\%) could be observed after 3 days in all geopolymers (Table 7). The reduction of thermonatrite over time, which was already detected in the discs, was confirmed with the powders. The largest amount of thermonatrite at the beginning of geopolymerization was calculated and observed in GP1 (theoretical amount $=11.19 \mathrm{wt} . \%$; measured amount $=22.11 \mathrm{wt} . \%)$. The large deviation between the theoretical and measured amounts of thermonatrite for GP1 was explained by the larger $\mathrm{s} / \mathrm{l}$ ratio in the geopolymer and, therefore, a larger surplus of $\mathrm{Na}^{+}$than estimated. The measured amounts of thermonatrite in GP2 to GP6 were within the range of estimation and measurement error. The increasing amount of thermonatrite with increasing s/l could be confirmed at least for GP4 to GP6. The amount of thermonatrite measured in GP7 (5.28 wt.\%) was less than the estimated amount $(7.9 \mathrm{wt} . \%)$. The largest $\mathrm{s} / 1$ ratio in GP7 of all samples could result in a denser fabric with trapping of free $\mathrm{Na}^{+}$and hindered air exposure and, thus, reduced carbonation.

Table 7. Amounts of minerals present in powdered geopolymers (wt.\% after 3 days, 28 days, and 3 months; measured by XRD and calculated using Autoquan)

\begin{tabular}{|c|c|c|c|c|c|c|c|}
\hline & GP1 & GP2 & GP3 & GP4 & GP5 & GP6 & GP7 \\
\hline \multicolumn{8}{|l|}{3 days } \\
\hline Thermonatrite & 22 & 8 & 7 & 5 & 7.5 & 8 & 5 \\
\hline Trona & 3.5 & 2 & 3 & 1 & 1 & 2 & 1.5 \\
\hline Quartz & 1.5 & 1 & 1 & 0.5 & 0.5 & 0.8 & 1 \\
\hline Anatase & 1 & 0.5 & 0.2 & 0.1 & 0.1 & 0.1 & 0.1 \\
\hline Muscovite & 1.5 & 1 & 3 & 2 & 2 & 2 & 2.5 \\
\hline Amorphous phase & 71 & 87.5 & 85 & 92 & 89 & 87 & 90 \\
\hline \multicolumn{8}{|l|}{28 days } \\
\hline Thermonatrite & 15 & 0 & 0 & 0 & 0 & 0 & 0.5 \\
\hline Trona & 2 & 2 & 2 & 1 & 3 & 2 & 2 \\
\hline Quartz & 1 & 1 & 1 & 0.5 & 1 & 1 & 1 \\
\hline Anatase & 0.5 & 0.1 & 0.1 & 0.1 & 0.1 & 0.1 & 0.1 \\
\hline Muscovite & 2.5 & 1 & 1 & 1 & 1 & 2 & 2 \\
\hline Amorphous phase & 78 & 96 & 96 & 98 & 95 & 95 & 94 \\
\hline \multicolumn{8}{|l|}{3 months } \\
\hline Thermonatrite & 0 & 0 & 0 & 0 & 0 & 0 & 0 \\
\hline Trona & 2 & 2 & 2 & 1 & 3 & 2 & 2 \\
\hline Quartz & 1 & 1 & 1 & 0.5 & 1 & 1 & 1 \\
\hline Anatase & 0.1 & 0.1 & 0.1 & 0.1 & 0.1 & 0.1 & 0.1 \\
\hline Muscovite & 1 & 1 & 1 & 1 & 1 & 2 & 2 \\
\hline Amorphous phase & 95 & 96 & 96 & 98 & 95 & 95 & 94 \\
\hline
\end{tabular}




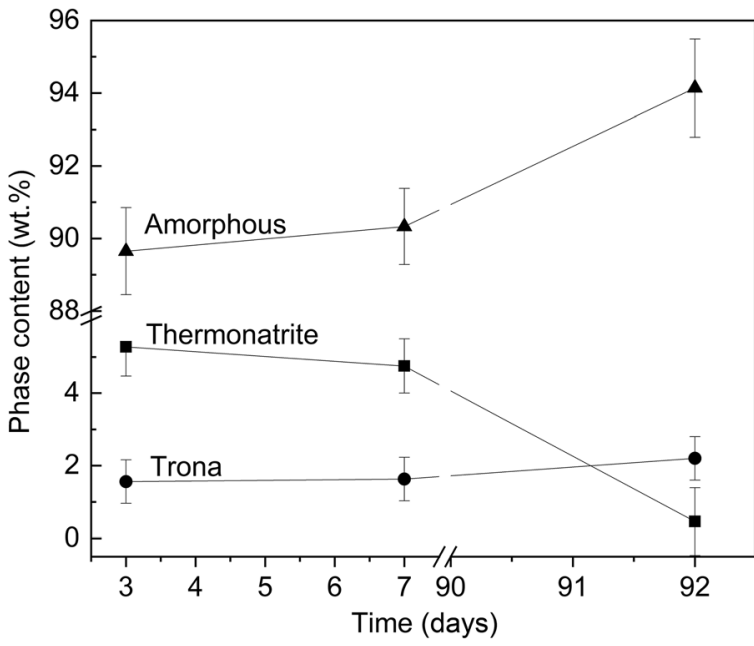

Fig. 5 Time-dependent change in mineralogical content of GP7 (from 3 days to 3 months)

While the quantity of thermonatrite decreased over time, the amorphous content increased (Fig. 5). The amount of trona remained approximately the same (variation of $<1 \%$ ). The decrease in the amount of thermonatrite and a nearly constant, small amount of trona in the powder samples, combined with the increase in amorphous phase, indicated that geopolymerization took place for far longer than $24 \mathrm{~h}$. The continuing dissolution of metakaolinite led to the subsequent binding of free $\mathrm{Na}^{+}$and, therefore, a reduction of thermonatrite. After 28 days, GP1 still contained $15.13 \mathrm{wt} . \%$ thermonatrite, GP7 contained $<0.5 \mathrm{wt} . \%$. After 3 months, thermonatrite could be detected in none of the powder samples. After 28 days, the increase in the amorphous phase was marginal for GP2-7, but GP1 showed a significant increase until 3 months. Geopolymerization in the discs could have been inhibited by the fast hardening, but, in the solid samples, thermonatrite also disappeared and the amount of amorphous material increased over time.

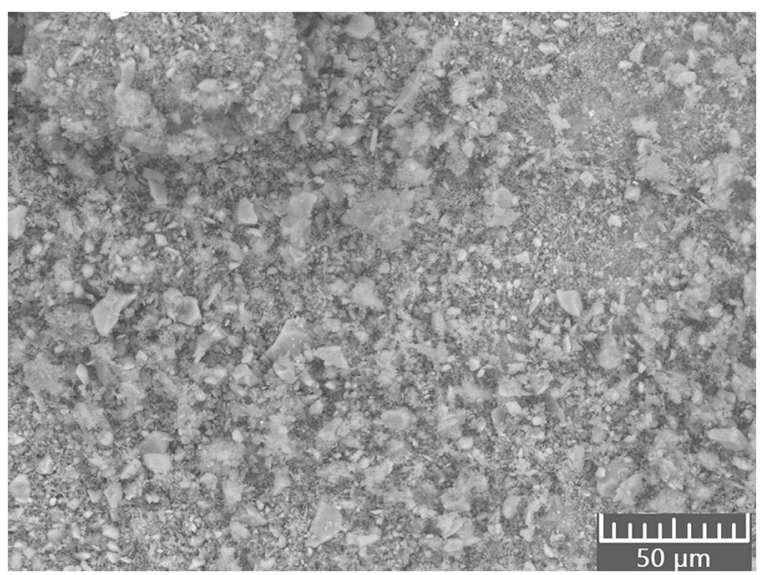

Fig. 6 SEM image of an air-exposed surface of GP4

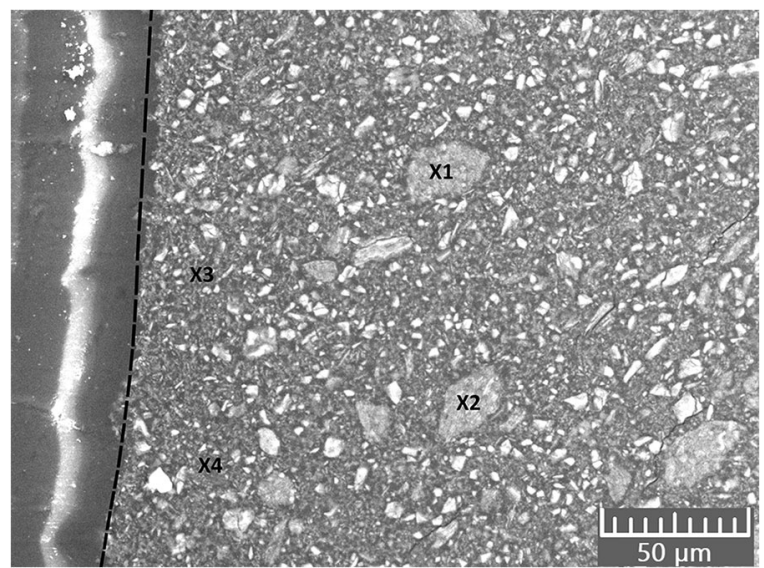

Fig. 7 SEM image of a polished section of GP4 (the dashed line marks the edge of the sample)

\section{Microstructural Properties of Geopolymers}

The unpolished samples showed a rough surface (e.g. GP4; 4 months; Fig. 6). The element ratios reflected the components added at geopolymer production (Na:Al 1:1 and Si:Al 3:1), but spots with a surplus of $\mathrm{Na}$ were observed up to $\mathrm{Na}$ :Al ratios of $2.25: 1$, indicating remaining trona deposits at the surface.

The micrographs of the polished cross sections revealed that the geopolymers consisted of a fine-grained matrix with a homogeneous distribution of bigger particles throughout the entire sample thickness. No reaction front of carbonates was detected at the surface of the samples (Fig. 7), by which the penetration depth of the carbonates within the geopolymer could be examined. The Si:Al ratio was $\sim 1.5: 1$ for the bigger particles (X1 and X2, Fig. 7) and 2.5:1 for the matrix (X3 and X4, Fig. 7). Both the particles and the matrix showed a Na:Al ratio of only $0.5: 1$, however. A few spots with $\mathrm{Si}: \mathrm{Al}$ ratios up to $7: 1$ were found, which indicate agglomerated, unreacted $\mathrm{SiO}_{2}$ attached to the geopolymer matrix. Aggregates of unreacted $\mathrm{SiO}_{2}$, together with a geopolymer matrix of about stoichiometric composition, showed that the raw materials were not converted completely into geopolymers.

\section{SUMMARY AND CONCLUSION}

Incomplete and/or delayed dissolution of metakaolinite in $\mathrm{NaOH}$ resulted in a surplus of reactive $\mathrm{Na}^{+}$of stoichiometrically mixed educts. $\mathrm{Na}^{+}$reacted with airborne $\mathrm{CO}_{2}$ to form thermonatrite during the early stage of hardening. Ongoing exposure to the atmosphere of the freshly prepared geopolymer caused an increase in $\mathrm{CO}_{2}$ incorporation during consumption of thermonatrite and the formation of trona. The progressive dissolution of the metakaolinite and geopolymerization reduced the formation of trona. Further studies are needed to show the influence of carbonation on mechanical strength and durability of geopolymers as well as on the $\mathrm{pH}$ value of geopolymers and its impact on steel corrosion. Furthermore, the $\mathrm{s} / \mathrm{l}$ ratio at the same metakaolinite content had an impact on carbonation. The coupled influence on workability, extent of 
thermonatrite formation, and mechanical strength also require study.

The incomplete dissolution of the amorphous silica added resulted in smaller $\mathrm{Si}: \mathrm{Al}$ ratios within the geopolymers in relation to the initial stoichiometric calculations with no influence on carbonation but with a possible influence on mechanical strength. While a reduced Si:Al ratio reduces the mechanical strengths of geopolymers, amorphous $\mathrm{SiO}_{2}$ fillers could increase the mechanical strength of construction materials by increasing bulk density and decreasing porosity. The combined influence needs to be studied in detail for practical applications. The presolution of amorphous $\mathrm{SiO}_{2}$ in $\mathrm{NaOH}$, e.g. at moderate temperatures, prior to mixing with metakaolinite should be considered.

\section{ACKNOWLEDGMENTS}

This project was funded by Deutsche Forschungsgemeinschaft under EM79/8-1. The ICP-OES measurements were performed by Marita Heinle, Institute of Functional Interfaces, Karlsruhe Institute of Technology (KIT), Karlsruhe, Germany.

\section{Funding}

Open Access funding was provided by Projekt DEAL. Funding sources are as stated in the Acknowledgments.

\section{Compliance with Ethical Statements}

\section{Conflict of Interest}

The authors declare that they have no conflict of interest.

Open Access This article is licensed under a Creative Commons Attribution 4.0 International License, which permits use, sharing, adaptation, distribution and reproduction in any medium or format, as long as you give appropriate credit to the original author(s) and the source, provide a link to the Creative Commons licence, and indicate if changes were made. The images or other third party material in this article are included in the article's Creative Commons licence, unless indicated otherwise in a credit line to the material. If material is not included in the article's Creative Commons licence and your intended use is not permitted by statutory regulation or exceeds the permitted use, you will need to obtain permission directly from the copyright holder. To view a copy of this licence, visit http://creativecommons. org/licenses/by/4.0/.

\section{REFERENCES}

Alexander, G. B., Heston, W., \& Iler, R. K. (1954). The solubility of amorphous silica in water. The Journal of Physical Chemistry, 58, 453-455.

Bauer, A., \& Berger, G. (1998). Kaolinite and smectite dissolution rate in high molar $\mathrm{KOH}$ solutions at 35 and $80^{\circ} \mathrm{C}$. Applied Geochemistry, 13, 905-916.

Chermak, J. (1992). Low temperature experimental investigation of the effect of high $\mathrm{pH} \mathrm{NaOH}$ solutions on the Opalinus Shale, Switzerland. Clays and Clay Minerals, 40, 650-658.
Crundwell, F. K. (2017). On the mechanism of the dissolution of quartz and silica in aqueous solutions. ACS Omega, 2, 1116-1127.

Cuevas, J., De La Villa, R. V., Ramírez, S., Sánchez, L., Fernández, R., \& Leguey, S. (2006). The alkaline reaction of FEBEX bentonite: a contribution to the study of the performance of bentonite/concrete engineered barrier systems. Journal of Iberian Geology, 32, 151174.

Davidovits, J. (1982). U.S. Patent No. 4,349,386. Washington, DC: U.S. Patent and Trademark Office.

Davidovits, J. (1991). Geopolymers: inorganic polymeric new materials. Journal of Thermal Analysis and Calorimetry, 37, 1633-1656.

Davidovits, J. (2013). Geopolymer cement. Geopolymer Science and Technics, Technical Paper \#21, Geopolymer Institute Library, France.

Djobo, J. N. Y., Elimbi, A., Tchakouté, H. K., \& Kumar, S. (2016). Mechanical activation of volcanic ash for geopolymer synthesis: effect on reaction kinetics, gel characteristics, physical and mechanical properties. RSC Advances, 6, 39106-39117.

Duxson, P., Provis, J. L., Lukey, G. C., Mallicoat, S. W., Kriven, W. M., \& Van Deventer, J. S. (2005). Understanding the relationship between geopolymer composition, microstructure and mechanical properties. Colloids and Surfaces A: Physicochemical and Engineering Aspects, 269, 47-58.

Esaifan, M., Rahier, H., Barhoum, A., Khoury, H., Hourani, M., \& Wastiels, J. (2015). Development of inorganic polymer by alkaliactivation of untreated kaolinitic clay: Reaction stoichiometry, strength and dimensional stability. Construction and Building Materials, 91, 251-259.

Faisal, M., Muhammad, K., \& Amin, W. (2015). Geopolymerization with bagasse bottom ash and china clay, effect of calcination temperature and silica to alumina ratio. RSC Advances, 5, 6781467819.

Fletcher, R. A., MacKenzie, K. J., Nicholson, C. L., \& Shimada, S. (2005). The composition range of aluminosilicate geopolymers. Journal of the European Ceramic Society, 25, 1471-1477.

Gao, X., Joussein, E., Michaud, P., \& Rossignol, S. (2014). Role of the synthesis method on the microstructure and mechanical properties of metakaolin-based potassium geopolymers. Ceramics-Silikáty, $58,215-222$.

Hájková, P. (2018). Kaolinite claystone-based geopolymer materials: Effect of chemical composition and curing conditions. Minerals, 8, 444.

He, J., Jie, Y., Zhang, J., Yu, Y., \& Zhang, G. (2013). Synthesis and characterization of red mud and rice husk ash-based geopolymer composites. Cement and Concrete Composites, 37, 108-118.

Heah, C. Y., Kamarudin, H., Mustafa Al Bakri, A. M., Bnhussain, M., Luqman, M., Khairul Nizar, I., et al. (2013). Kaolin-based geopolymers with various $\mathrm{NaOH}$ concentrations. International Journal of Minerals, Metallurgy, and Materials, 20, 313-322.

Herrmann, A., Koenig, A., \& Dehn, F. (2018). Structural concrete based on alkali-activated binders: Terminology, reaction mechanisms, mix designs and performance. Structural Concrete, 19(3), 918-929.

Izadifar, M., Thissen, P., Steudel, A., Kleeberg, R., Kaufhold, S., Kaltenbach, J., Schuhmann, R., Dehn, F., \& Emmerich, K. (2020) Comprehensive examination of dehydroxylation of kaolinite, disordered kaolinite, and dickite: Experimental studies and Density Functional Theory. Clays and Clay Minerals, 68. https://doi. org/10.1007/s42860-020-00082-w.

McLellan, B. C., Williams, R. P., Lay, J., van Riessen, A., \& Corder, G. D. (2011). Costs and carbon emissions for geopolymer pastes in comparison to ordinary portland cement. Journal of Cleaner Production, 19, 1080-1090.

Mellado, A., Catalán, C., Bouzón, N., Borrachero, M., Monzó, J., \& Payá, J. (2014). Carbon footprint of geopolymeric mortar: study of the contribution of the alkaline activating solution and assessment of an alternative route. RSC Advances, 4, 23846-23852.

Moosberg-Bustnes, H., Lagerblad, B., \& Forssberg, E. (2004). The function of fillers in concrete. Materials and Structures, 37, 74. 
Nikolov, A., Rostovsky, I., \& Nugteren, H. (2017). Geopolymer materials based on natural zeolite. Case Studies in Construction Materials, 6, 198-205.

Oh, J. E., Monteiro, P. J. M., Jun, S. S., Choi, S., \& Clark, S. M. (2010). The evolution of strength and crystalline phases for alkali-activated ground blast furnace slag and fly ash-based geopolymers. Cement and Concrete Research, 40, 189-196.

Ozer, I., \& Soyer-Uzun, S. (2015). Relations between the structural characteristics and compressive strength in metakaolin based geopolymers with different molar $\mathrm{Si} / \mathrm{Al}$ ratios. Ceramics International, 418, 10192-10198.

Rowles, M., \& O'Connor, B. (2003). Chemical optimisation of the compressive strength of aluminosilicate geopolymers synthesised by sodium silicate activation of metakaolinite. Journal of Materials Chemistry, 13, 1161-1165.

Tchakouté, H. K., Rüscher, C. H., Kong, S., Kamseu, E., \& Leonelli, C. (2016). Geopolymer binders from metakaolin using sodium waterglass from waste glass and rice husk ash as alternative activators: a comparative study. Construction and Building Materials, 114, 276-289.

Tchakouté, H. K., Rüscher, C. H., Hinsch, M., Djobo, J. N. Y., Kamseu, E., \& Leonelli, C. (2017). Utilization of sodium waterglass from sugar cane bagasse ash as a new alternative hardener for producing metakaolin-based geopolymer cement. Geochemistry, 77(2), 257-266.

Xu, H., \& Van Deventer, J. S. J. (2000). The geopolymerisation of alumino-silicate minerals. International Journal of Mineral Processing, 59, 247-266.

Xu, H., \& van Deventer, J. S. J. (2003). The effect of alkali metals on the formation of geopolymeric gels from alkali-feldspars. Colloids and Surfaces A: Physicochemical and Engineering Aspects, 216, 27-44.

Yaseri, S., Hajiaghaei, G., Mohammadi, F., Mahdikhani, M., \& Farokhzad, R. (2017). The role of synthesis parameters on the workability, setting and strength properties of binary binder based geopolymer paste. Construction and Building Materials, 157, 534 545.

Zaharaki, D., Komnitsas, K., \& Perdikatsis, V. (2010). Use of analytical techniques for identification of inorganic polymer gel composition. Journal of Materials Science, 45, 2715-2724.

(Received 14 April 2020; revised 5 August 2020; AE: Andrey G. Kalinichev) 